\title{
Investigating Service Quality Initiatives of Pakistani Commercial Banks
}

\author{
Shaukat Ali Raza \\ Assistant Professor/In-Charge, Department of Business Education, IER, University of the Punjab \\ Lahore, Pakistan \\ Tel: 92-300-430-8614 E-mail: shaukat_ali_5@yahoo.com
}

Shahid A. Zia

Chairman, Media MARCON, Council Member, Marketing Association of Pakistan

Lahore, Pakistan

Syed Abir Hassan Naqvi

Lecturer, Department of Technology Education, IER, University of the Punjab

Lahore, Pakistan

Tel: 92-321-843-7373 E-mail: professor_abir@yahoo.com

Asghar Ali

Graduating student of Department of Business Education, IER, University of the Punjab

Lahore, Pakistan

Received: September 19, 2011

Accepted: January 27, 2012

Published: March 1, 2012

doi:10.5539/ibr.v5n3p107

URL: http://dx.doi.org/10.5539/ibr.v5n3p107

\begin{abstract}
The study investigated the service quality initiatives taken by Pakistani commercial banks in Lahore based on the perceptions of 447 respondents, selected by using multistage random sampling technique, through SERVQUAL scale which was found reliable at 0.866 Cronbach's alpha. Mean scores, alphas, and correlations were calculated. One-Sample $t$-test, Independent Samples $t$-test, and One-way ANOVA were employed for significance and variance analysis. The study concluded that customers, employees, and managers respectively were not satisfied with the overall service quality provided by the Pakistani banks in terms of five sub-scales of service quality. However, tangibles were relatively at top whereas assurance was at the lowest position. Reliability and empathy were at almost similar level and banks failed in their responsiveness. Pakistani banks need to revisit their quality initiatives and focus on responsiveness, assurance, reliability, empathy, and tangibles in order of priority to ensure the set standards of service quality.
\end{abstract}

Keywords: Service quality, Tangibles, Reliability, Responsiveness, Assurance, Empathy

\section{Introduction}

Quality, the buzz word of $21^{\text {st }}$ century, is a vital reflection of organizational performance and the subject of contemporary research in business world which has influenced academia as well (Yavas \& Yasin, 2001; Karatepe, Yavas \& Babakus, 2005) leading to the concept of corporate university in the literature on higher education (Ali, 2008). Deming (1982) is famous for introducing the quality construct in US industry. Since then, different dimensions of quality are under discussion in manufacturing, trading and service business in different cultures around the globe. What quality really means in banking; how stakeholders perceive it; what areas of indigenous banking quality are relatively stronger; and which local banks are performing better, are significant dimensions of the current study investigating perceptions of customers, employees, and managers about the service quality initiatives taken by Pakistani commercial banks in terms of tangibles, reliability, responsiveness, assurance, and empathy as sub-scales of quality. 


\section{Review of Literature}

\subsection{Service Quality Concept}

Quality is perceived differently by different people. Business Dictionary (2010) depicts quality as measures of excellence; observable and interpretable attributes; or the adherence to measurable and verifiable standards. But, quality could not be understood until one compares characteristics with requirements of the user and that is actually a question of degree to which the former comply with the later; a measure of relativity (Praxiom Research Group, 2010). Quite opposite to goods quality, service quality is intangible in nature and hard to measure in objective terms compelling managers and researchers to measure it through perceptions of the customers (Karatepe, Yavas \& Babakus, 2005) who pay its price. As technology has enhanced the growth of service delivery to customers (Dabholkar \& Bagozzi 2002), service quality is also measured in terms of automated service (Parasuraman, Zeithmal, \& Malhotra, 2005) that is an electronic provision of service (Buckley, 2003) possible through information and communication technology (Surjadjaja, Ghosh \& Antony, 2003) and businesses like banks may enhance the quality of their services and customer relations (Mols, 2000) using this system.

These initiatives taken by banks and other service organizations to ensure quality, is a matter of customer satisfaction. An acceptable level of service quality leads to customer satisfaction, attraction of new customers and customer retention (Lassar, Manolis \& Winsor, 2000; Karatepe, Yavas \& Babakus, 2005; Ibrahim, Joseph \& Ibeh, 2006). Keeping in view the rating by price paying customers, the entrepreneurial view of the service quality dictates that the degree of customer satisfaction really determines the level of success or failure of the business (Santos, 2003).

\subsection{Measuring the Service Quality}

If service quality matters this much, it must have been a regular phenomenon at all organizations. The description of service quality could be traced back in 1960s (Karatepe, Yavas \& Babakus, 2005) but its measurement got ground from the pioneer work of Parasuraman, Berry and Zeithmal (1985) that led to the first formal measurement of service quality by Parasuraman, et al. (1988) through the famous tool namely SERVQUAL and the interest in topic gained high acceleration during the past twenty years or so (Karatepe, Yavas \& Babakus, 2005). Different studies (Cronin \& Taylor, 1992; Cronin \& Taylor 1994; Newman, 2001; Aldlaigan \& Buttle, 2002; Greenland, Coshall, \& Combe, 2005) have established the worth of SERVQUAL as a service quality measurement tool. However, what is measured as quality is a matter of serious concern and the following lines encompass its scope.

The literature on service quality provides different dimensions researchers have identified such as expectations, outcome and image (Gronroos, 1984); tangibles, reliability, responsiveness, assurance, and empathy (Parasuraman et al., 1988); service product, service environment, and service delivery (Rust \& Oliver, 1994); interaction quality, physical environment quality, and outcome quality (Brady \& Cronin, 2001); service environment, interaction quality, empathy, reliability, customer satisfaction, purchase intention (Karatepe, Yavas \& Babakus, 2005); and tangibles, courtesy, reliability, customer understanding, and assurance (Cauchick Miguel, Silva, Chiosini \& Schutzer, 2009). Despite this debate on dimensionality, SERVQUAL is still a widely used instrument adapted for different services and cultures (Imrie, Cadogan \& McNaughton, 2002; Long \& McMellon 2004). Ibrahim, Joseph, and Ibeh (2006), Şafakli (2007), Petridou, Spathis, Glaveli and Liassides (2007), and Ravichandran, Prabhakaran and Kumar (2010) reported their investigations of quality on SERVQUAL specifically in banking sector.

In SERVQUAL, tangibles refer to the appearance of physical facilities, equipment, personnel, and communication materials (Parasurman et al. 1988, 1991), counter partitions in the bank (Othman \& Owen, 2003), overall appearance of branches (Jabnoun \& Al-Tamimi, 2003), and a distinct aspect that does show consistency across cultures (Cui, Lewis \& Won Park, 2003). Reliability is the bank's ability to perform the promised service with dependability and accuracy (Osman \& Ali, 2009). Responsiveness is willingness of staff to help customers and provide prompt service (Parasurman et al., 1994; Jabnoun \& Al-Tamimi, 2003; Sureshchandar, Rajendran \& Anantharaman, 2003). Assurance reflects employee attitudes and behavior and the ability of staff to provide a competent, confidential and courteous service, and ability of staff to be friendly (Newman, 2001). And at the end, empathy is the care and individualized attention the organization provides to its customers (Parasurman, et al, 1994; Greenland, et al., 2005).

The SERVQUAL, as noted above, has been used in different cultures and service sectors including banking. Such efforts were made mostly outside Pakistan. The current study was designed to investigate perceptions of customers, employees, and managers about the service quality initiatives taken by Pakistani commercial banks in terms of tangibles, reliability, responsiveness, assurance, and empathy as sub-scales of quality. More specifically, the study pursued the following objectives: 
1. explore opinions of customers, employees, and managers of banks regarding service quality of banks in terms of tangibles, reliability, responsiveness, assurance, and empathy as sub-scales;

2. compare the perceptions of customers, employees, and managers of banks regarding service quality of banks in terms of tangibles, reliability, responsiveness, assurance, and empathy as sub-scales; and

3. compare the perceptions of customers, employees, and managers of banks regarding service quality of banks in terms of background variables.

\section{Methodology}

\subsection{Sample}

The service quality of banks is intangible and could be measured through the perceptions of those who are benefiting from it (Karatepe, Yavas \& Babakus, 2005). Therefore, the sample included managers, employees and customers. There were 04 public and 20 private banks in Lahore affiliated with the State Bank of Pakistan by September 2010. Out of these, one public and five private banks were selected through $25 \%$ stratified random sampling technique. There were 357 branches of these banks in Lahore from which 36 (10\% approx) were randomly selected. Hence, a sample of 36 managers, 144 employees and 360 customers was selected taking 1 manager, 4 employees and 10 customers each from 36 branches of sample banks.

\subsection{Data Collection and Analysis}

A SERVQUAL used in banking sector was adopted from Şafakli (2007), which was found reliable at 0.866 Cronbach's alpha for the purpose of current study. Data were collected by second and third researchers.

The responses of respondents were quantified ranging fron 05 for strongly agreed and 01 for strongly disagree. Mean score 03 was taken as cut point (Aksu, 2003) and mean scores 03 and below were taken as representing inadequate measures of service quality. Whereas, mean scores above 03 were taken as representing adequate measures of service quality of banks. Mean scores, alphas, and correlations were calculated for the five sub-scales namely tangibles, reliability, responsiveness, assurance, and empathy. One-Sample t-test, Independent samples t-test, and One-way ANOA were employed for significance and variance analysis.

\section{Results}

A total of 447 responses, 36 manager (100\%), 118 out of 144 employees (81.94\%) and 293 out of 360 customers $(81.39 \%)$ were received thus giving an overall response rate of $82.78 \%$. The gender split of these respondents revealed that majority of managers $(77.8 \%)$, employees $(55.1 \%)$ and customers $(67.6 \%)$ was male. As a whole, 294 (66 \%) respondent were males and 153 (34 \%) were females. Bank affiliation was noticed as Bank Alflah (BA) 60 (13\%), Allied Bank (ABL) 90 (20\%), Bank of Punjab (BOP) 63 (14\%), MCB Bank (MCB) 114 (26\%), United Bank (UBL) 64 (14\%), and Standard Chartered Bank (SC) 56 (13\%). These respondents were Graduate (142, $32 \%)$, Master (267, $60 \%)$, MPhil (6, $01 \%), \operatorname{PhD}(3,01 \%)$, and other (29, $06 \%$ ) degree holders.

The correlations (table 1) are week within sub-scales against those with the SERVQUAL and this situation validates these factors of the scale and their alpha values ranging from 0.638 to 0.702 (table 2) point out that these fall in acceptable range (Gursoy \& Umbreit, 2005; Raza, Majid \& Zia, 2010) enhancing further the validity of the scale.

One-Sample statistics for service quality dimensions as given in table 2 indicate that tangible aspect of service quality of banks got the highest position. Reliability and empathy were almost at same level. Below these was assurance and responsiveness fell in rejection region as its mean value is below 03.

Analysis of background variables revealed that female respondents were more satisfied with service quality of banks as compared with males. In respondents, customers were less satisfied with the service quality of banks as compared with employees and managers. In banks, BA was leading in tangible category followed by ABL, and MCB. ABL was leading in reliability, empathy, assurance and responsiveness followed by BA. ABL and BA in reliability; ABL and $\mathrm{BA}$ in responsiveness; $\mathrm{ABL}$ in assurance; and $\mathrm{ABL}, \mathrm{MCB}$, and $\mathrm{UBL}$ in empathy were significantly better than other sample banks.

\section{Discussion}

The significance of SERVQUAL as a service quality measurement tool is established, but studies like Gronroos (1984), Dabholkar, and Bagozzi (2002, Imrie, Cadogan and McNaughton (2002), Cui, Lewis, and Won Park (2003), Long and McMellon (2004), Greenland, Coshall and Combe (2005), Ibrahim, Joseph and Ibeh (2006) and Şafakli (2007) pointed out that the situation of service quality is different in various countries and cultures. One possible reason of this tendency could be the difference in the perceptions of the users of service quality in different countries 
and cultures. This tendency would verify the similarities/dissimilarities of the findings of current study with those referred in 2.1 and 2.2 above.

\subsection{Service Quality of Pakistani Banks}

The first objective of the study was to explore opinions of customers, employees, and managers of banks regarding service quality of banks in terms of tangibles, reliability, responsiveness, assurance, and empathy as sub-scales. The findings of the study revealed that the overall situation of service quality of banks is unsatisfactory as the average mean score for all the five aspects of quality is 3.5 which is below 04 , the point of agreement of respondents on the survey scale. It means that respondents show their disagreement on providing quality services to the stakeholders by the banks. In this unhealthy state of affairs, the condition of tangibles (4.425) is relatively better and falls above the level of agreement of respondents on the service quality of banks at SERVQUAL. This finding is consistent with Petridou et al. (2007) and Ravichandran, Prabhakaran and Kumar (2010). It means that Pakistani banks are providing good tangible facilities to the customers. Reliability (3.729) and empathy (3.631) are almost at same level which is below the agreement of respondents at the rating scale. The case of assurance (3.098) also falls in the same category. However, the respondents have rejected the responsiveness (2.812) ability of banks. These finding being contradictory to the dictates of total quality standards, are highlighting Pakistani banks facing this critical situation, especially in responsiveness where bank staff is not willing to provide prompt services to their customers. Findings also point out the inability of Pakistani banks to compete with foreign banks operating in Pakistan at the one hand, and support the report of rating agencies highlighting the problems these banks are facing at the other.

\subsection{Comparison of Respondents' Opinion}

The second objective of the study was to compare the perceptions of customers, employees, and managers of banks regarding service quality of banks in terms of tangibles, reliability, responsiveness, assurance, and empathy as sub-scales. Findings of the study revealed that customers were less satisfied with the service quality of banks in terms of the sub-scales as compared with employees and managers. Further analysis indicated that employees were less satisfied with the service quality of banks as compared with managers. The point of view of employees who directly face customers at different bank counters, actually verifies the reservations of customers. This may also reflect the managers' defensive position being part of the top management. But the opinion of employees, especially the customers who are not satisfied with the service quality of banks, needs to be considered. One possible cause of this need is the unacceptable level of service quality for customer satisfaction and retention (Ibrahim, Joseph \& Ibeh, 2006) that determines the level of success of the banks (Santos, 2003).

\subsection{Background Variables vs Service Quality}

The third objective of the study was to compare the perceptions of customers, employees, and managers of banks regarding service quality of banks in terms of background variables. Analysis of background variables revealed that males, the majority segment, were unhappy with all aspects of the service quality of banks. This trend gets intensified in respondents' analysis in 5.2 where customers were less satisfied with the service quality of banks as compared with employees and managers. These findings provide serious insights to the banking leaders who need to satisfy customers for survival in the growing competition. In bank category, BA was leading in tangibles followed by $\mathrm{ABL}$ and $\mathrm{MCB}$. $\mathrm{ABL}$ was leading in reliability, empathy, assurance and responsiveness followed by $\mathrm{BA}$. $\mathrm{ABL}$ and $\mathrm{BA}$ in reliability; $\mathrm{ABL}$ and $\mathrm{BA}$ in responsiveness; $\mathrm{ABL}$ in assurance; and $\mathrm{ABL}, \mathrm{MCB}$, and UBL in empathy were significantly better than other sample banks. The bank-wise analysis revealed that the privatized banks were performing better as compared with those in the public sector. One possible cause of this trend may be the smaller contribution of public sector in the sample of the current study. But, these findings really get support from the usual quality available at public banks, especially from the harsh behavior of their employees with customer. These findings also signify the need for privatization of service sector in order to improve cost and enhance managerial efficiencies for the uplift of this important segment of economy.

\section{Conclusion and Recommendations}

Though the female component is quite reasonable, males are still the majority segment of users of banking quality in Pakistan. The results of service quality initiatives taken by banks are not satisfactory and the most important stakeholders, the customers, are unhappy with the quality banks are providing to them in terms of tangibles, reliability, responsiveness, assurance, and empathy. The condition of tangibles available at Pakistani banks is relatively better as compared with other aspects of service quality. Reliability and empathy are almost at same level which is below the point of satisfaction of respondents. The case of assurance also falls in the same category. However, the respondents have rejected the responsiveness ability of Pakistani banks. The privatized banks are performing better as compared with those in public sector. The small size of the sample could be a limitation of this study; even then the findings represent the second largest city of the country and point out serious intimidation for 
the banking leaders who need to revisit their entrepreneurial endeavors. Banks, especially those in public sectors should take remedial measures to improve upon the situation or they may face consequences like postal and telecommunication services of Pakistan. Improvement of services along with training of employees could be a better solution. Political as well as business leaders should join hands to accelerate the privatization process at standards acceptable to stakeholders.

\section{References}

Aksu, M. B. (2003). TQM readiness level perceived by the administrators working for the central organization of the Ministry of National Education in Turkey. Total Quality Management \& Business Excellence, 14(5), 595-608. http://dx.doi.org/10.1080/1478336032000053609

Aldlaigan, A., \& Buttle, F. (2005). Beyond satisfaction: customer attachment to retail banks, International Journal of Bank Marketing, 23(4), 349-359. http://dx.doi.org/10.1108/02652320510603960

Aldlaigan, A. H., \& Buttle, F. A. (2002). SYSTRA-SQ: a new measure of bank service quality. International Journal of Service Industry Management, 13(4), 362-381. http://dx.doi.org/10.1108/09564230210445041

Ali, S. (2008). Faculty Development Program for Universities of Pakistan: The Need to Develop a Model. Unpublished Doctoral Thesis. University of the Punjab. Pakistan: Lahore.

Brady, M. K., \& Cronin Jr., J. J. (2001). Some new thoughts on conceptualizing perceived service quality: a hierarchical approach. Journal of Marketing, 65(3), 34-49. http://dx.doi.org/10.1509/jmkg.65.3.34.18334

Buckley, J (2003). E-service and the public sector. Managing Service Quality, 13(6), 453-462. http://dx.doi.org/10.1108/09604520310506513

Business Dictionary (2010). Definition of Quality. Retrieved on November 9, 2010 from http://www.businessdictionary.com/definition/quality.html\#ixzz14nV5cEH0.

Cauchick Miguel, P. A., Silva, M. T., Chiosini, E. L., \& Schutzer, K. (2009). Assessment of service quality dimensions: a study in a vehicle repair service chain. Retrieved on November 9, 2010 from http://www.idr.edu.vn/diendannghiencuu/showthread.

Cronin, J., \& Taylor S. (1994). SERVPERF versus SERVQUAL: Reconciling performance based and perceptions-minus-expectations measurement of service quality. Journal of Marketing, 58(1), 125-131. http://dx.doi.org/10.2307/1252256

Cronin, J., \& Taylor, S. (1992). Measuring SQ: re-examination and extension. Journal of Marketing, 56, 55-68. http://dx.doi.org/10.2307/1252296

Cui, C. C., Lewis, B. R., \& Won, P. (2003). Service Quality Measurement in the Banking Sector in South Korea. International Journal of Bank Marketing, 21(4), 191-201. http://dx.doi.org/10.1108/02652320310479187

Dabholkar, P., \& Bagozzi, R. (2002). An attitudinal Model of Technology-based Self-Service: Moderating effects of Consumers Traits and Situational Factors. Journal of Academy of Marketing Science, 30(3), 184-201. http://dx.doi.org/10.1177/0092070302303001

Deming, W. E. (1982). Out of the Crisis. Massachusetts Institute of Technology, Center for Advance Educational Services, Massachusetts.

Greenland, S., Coshall, J., \& Combe, I. (2005). Evaluating service quality and customer satisfaction in emerging markets. International Journal of Consumer Studies, 30(6), 582-590. http://dx.doi.org/10.1111/j.14706431.2005.00484.x

Gronroos, C. (1984). A service quality model and its marketing implications. European Journal of Marketing, 18(4), 36-44. http://dx.doi.org/10.1108/EUM0000000004784

Gursoy, D., \& Umbreit, W. T. (2005). Exploring students' evaluation of teaching effectiveness: What factors are important?. Journal of Hospitality \& Tourism Research, 29(1), 91-109. http://dx.doi.org/10.1177/1096348004268197

Ibrahim, E., Joseph, M., \& Ibeh, K. (2006). Customers' perception of electronic service delivery in the UK retail banking sector. International Journal of Bank Marketing, 24(7), 475-493. http://dx.doi.org/10.1108/02652320610712094

Imrie, B. C., Cadogan, J. W., \& McNaughton, R. (2002). The service quality construct on a global stage. Managing Service Quality, 12(1), 10-18. http://dx.doi.org/10.1108/09604520210415353 
Jabnoun, N., \& Al-Tamimi, H. (2003). Measuring perceived service quality at UAE Commercial Banks. International Journal of Quality \& Reliability Management, 20(4), 458-472. http://dx.doi.org/10.1108/02656710310468614

Karatepe, O. M., Yavas, U., \& Babakus, E. (2005) Measuring service quality of banks: Scale development and validation. Journal of Retailing and Consumer Services, 12(5), 373-383. http://dx.doi.org/10.1016/j.jretconser.2005.01.001

Lassar, W. M., Manolis, C., \& Winsor, R. D. (2000). Service quality perspectives and satisfaction in private banking. International Journal of Bank Marketing, 18(4), 181-199. http://dx.doi.org/10.1108/02652320010349067

Long, M., \& McMellon, C. (2004). Exploring determinants of retail service quality on the internet. Journal of Service Marketing, 18(1), 78-90. http://dx.doi.org/10.1108/08876040410520726

Mols, N. (2000). The internet and service marketing-the case of Danish retail banking. Internet research: Electronic Networking Applications and Policy, 10(1), 7-18. http://dx.doi.org/10.1108/10662240010312093

Newman, K. (2001). Interrogating SERVQUAL: a critical assessment of service quality measurement in a high street retail bank. International Journal of Bank Marketing, 19(3), 126-139. http://dx.doi.org/10.1108/02652320110388559

Osman, I., \& Ali, H. (2009). Customers Satisfaction in Malaysian Islamic Banking. International Journal of Economics and Finance, 1(1), 197-202.

Othman, A. Q., \& Owen, L. (2003). Managing and measuring customer service quality in Islamic banks: A Study of Kuwait Finance House. International Journal of Islamic Financial Services, 3(1), 6-12.

Parasuraman, A., Zeithaml, V., \& Malhotra, A. (2005). E-S-QUAL: A Multiple-Item Scale for Assessing Electronic Service quality. Journal of Service Research, 7(3), 213-234. http://dx.doi.org/10.1177/1094670504271156

Parasuraman, A., Berry, L., \& Zeithmal, V. (1985). A conceptual model of SQ and its implications for future research. Journal of Marketing, 49(3), 41-50. http://dx.doi.org/10.2307/1251430

Parasuraman, A., Berry, L., \& Zeithmal, V. (1994). Reassessment of expectations as a comparison standard in measuring SQ: Implications for Further Research. Journal of Marketing, 58(1), 111-124. http://dx.doi.org/10.2307/1252255

Parasuraman, A., Berry, L., \& Zeithmal, V. (1988). SERVQUAL: A multi-item scale for measuring consumer perceptions of SQ. Journal of Retailing, 64(2), 12-40.

Parasuraman, A., Berry, L., \& Zeithmal, V. (1991). Perceived service quality as a customer-based performance measure: An empirical examination of organizational barriers using an extended service quality model. Human Resource Management, 30(3), 335-364. http://dx.doi.org/10.1002/hrm.3930300304

Petridou, E., Spathis, C., Glaveli, N., \& Liassides, C. (2007). Bank service quality: empirical evidence from Greek and Bulgarian retail customers. International Journal of Quality \& Reliability Management, 24(6), 568-657. http://dx.doi.org/10.1108/02656710710757772

Praxiom Research Group (PRG). (2010). ISO 9000, 9001, AND 9004: QUALITY MANAGEMENT DEFINITIONS. Retrieved on November 9, 2010 from http://www.praxiom.com/iso-definition.htm.

Ravichandran, K., Prabhakaran, S., \& Kumar, A. S. (2010). Application of Servqual Model on Measuring Service Quality: A Bayesian Approach. Enterprise Risk Management, 1(1), 145-169.

Raza, S. A., Majid, Z., \& Zia, A. (2010). Perceptions of Pakistani University Students about Roles of Academics Engaged in Imparting Development Skills: Implications for Faculty Development. Bulletin of Education \& Research, 32(2), 75-91.

Rust, R. T., \& Oliver, R. L. (1994). Service quality: insights and managerial implications from the frontier. In Rust, R. T., Oliver, R. L. (Eds.), Service Quality: New Directions in Theory and Practice (pp. 1-19). Thousand Oaks, CA: Sage Publications.

Safakli, O. V. (2007). Testing Servqual Dimensions on the Commercial Bank Sector of Northern Cyprus. Financial Theory and Practice, 31(2), 185-201.

Santos, J. (2003). E-service quality: a model of virtual service quality dimensions. Managing Service Quality, 13(3), 233-246. http://dx.doi.org/10.1108/09604520310476490 
Sureshchandar, G. S., Rajendran, C., \& Anantharaman, R. N. (2003). Determinants of customer-perceived service quality: A confirmatory factor analysis approach. The Journal of Services Marketing, 16(1), 9-34. http://dx.doi.org/10.1108/08876040210419398

Surjadjaja, H., Ghosh, S., \& Antony, J. (2003). Determining and assessing the determinants of eservice operations. Managing Service Quality, 13(1), 39-53. http://dx.doi.org/10.1108/09604520310456708

Yavas, U., Yasin, M. M. (2001). Enhancing organizational performance in banks: a systematic approach. Journal of Services Marketing. 15(6), 444-453. http://dx.doi.org/10.1108/EUM0000000006099

Table 1. Correlation between Sub-Scales and SERVQUAL

\begin{tabular}{cccccc}
\hline & Tangibles & Reliability & Responsiveness & Assurance & Empathy \\
\hline SERVQUAL & $0.587^{* *}$ & $0.730^{* *}$ & $0.732^{* *}$ & $0.668^{* *}$ & $0.737^{* *}$ \\
Tangibles & & $0.379^{* *}$ & $0.314^{* *}$ & $0.336^{* *}$ & $0.388^{* *}$ \\
Reliability & & $0.436^{* *}$ & $0.425^{* *}$ & $0.452^{* *}$ \\
Responsiveness & & & $0.454^{* *}$ & $0.442^{* *}$ \\
Assurance & & & & $0.380^{* *}$ \\
\hline
\end{tabular}

${ }^{* *}$ Correlation is significant at the 0.01 level (2-tailed).

Table 2. One-Sample Statistics for Service Quality Dimensions

\begin{tabular}{cccccc}
\hline Factors & Mean & SD & df & Alpha & $t$-Value \\
\hline Tangibles & 4.425 & 0.651 & 446 & 0.653 & $46.25^{*}$ \\
Reliability & 3.729 & 0.712 & 446 & 0.679 & $21.65^{*}$ \\
Empathy & 3.631 & 0.755 & 446 & 0.687 & $17.67^{*}$ \\
Assurance & 3.098 & 0.659 & 446 & 0.638 & $3.16^{*}$ \\
Responsiveness & 2.812 & 0.752 & 446 & 0.702 & $-5.28^{*}$ \\
\hline
\end{tabular}

${ }^{*} \mathrm{p}<0.05$. 